\title{
Investigating Habitat Suitability and Conservation Issues of Re-introduced Wild Water Buffalo in Chitwan National Park, Nepal
}

\section{Gaurav Dhungel ${ }^{1}$, Dol Raj Thanet $^{2 *}$ and Damodar Gaire ${ }^{2}$}

Abstract : With an ever present threat of extinction aggravated mostly by inbreeding, genetic introgression and flooding stress, translocation of wild water buffalo (Bubalus arnee) to another suitable habitat was a must since decades. Habitat suitability analysis for wild water buffalo has been done by using binary model in ArcGIS 10.2.2 and slope, elevation, distance to water bodies and land cover criteria were used to prepare habitat suitability map of Chitwan National Park. Vegetation compositions were assessed in the grassland of Old Padampur area in sample plots $(\mathrm{n}=36)$ each of size $1 \mathrm{~m} \times 1 \mathrm{~m}$ for grasses and $10 \mathrm{~m} \times 10 \mathrm{~m}$ for trees by using random sampling strategy. Conservation issues were identified through key-informant interviews and on-site observation of enclosure area, where re-introduced wild water buffalo were soft released. $127.13 \mathrm{~km}^{2}$ of the park area was identified as suitable habitat for wild water buffalo with around $79 \%$ of Old Padampur area. Importance Value Index (IVI) indicated that Saccharum spontaneum was found to be the most dominant grass species (IVI = 100.43) followed by Imperata cylindrica (IVI = 56.70) in Old Padampur area. Old Padampur area lies in the lap of Rapti River with many streams and marshes in the area which contributes to its suitability. The grassland of Old Padampur area is the largest in the park. At present, the wild water buffalo is facing some conservation issues mainly due to improper execution of soft release strategy and few uncontrolled natural events, such as floods and predators attacks. Therefore, to maintain the viable population of wild water buffalo in Chitwan National Park in the long-run, it is crucial to regulate and enhance effective soft release strategy and more advance techno-based modality in close coordination with conservation partners and relevant stakeholders.

Keywords: Importance Value Index, vegetation analysis, suitable habitat, translocation, Saccharum spontaneum, viable population

Dhungel G., Thanet D.R. (2019): Investigating Habitat Suitability and Conservation Issues of Re-introduced Wild Water Buffalo in Chitwan National Park, Nepal. Forestry: Journal of Institute of Forestry, Nepal. No. 16: page 1 to 13.

\footnotetext{
1 University of Kentucky, Department of Forestry and Natural Resources, Lexington, Kentucky, USA

${ }^{2}$ Tribhuwan University, Institute of Forestry, Hetauda Campus, Nepal.

*Corresponding Author,email: dolrajthanet@gmail.com
} 


\section{Introduction}

Wild water buffalo (Bubalus arnee Kerr 1972), also called Wild Asian Buffalo is a large bovine native to Southeast Asia (Dahmer 1978) which is listed as an endangered species in the IUCN Red List of Threatened Species since 1986, and in Appendix III of the Convention on International Trade in Endangered Species of wild fauna and flora (CITES) (Hedges et al. 2008). Once wild water buffalo were found throughout the lowland of South Asia, however at present, they are found in small range. In Nepal, they were recorded in Chitwan valley until 1960s, but they were extirpated from that area presumably because of disease carried by domestic cattle and buffalo (Seidensticker 1975). Furthermore, after the eradication of Malaria during 1954, people from mid-hills shifted to lowland of Tarai region for settlement and agricultural expansion, which resulted in the destruction and fragmentation of the habitat altering the natural ecosystem and biodiversity (Smith et al. 1998). Accordingly, most of the wild animals, especially large mammals are now restricted to the few pockets of protected areas in a small number because of the ongoing fragmentation of its habitat (Pradhan 2007). Now, wild water buffalo is confined to Koshi Tappu Wildlife Reserve (KTWR), which holds 441 individuals, the only viable population of Nepal (DNPWC 2018).

The wild water buffaloes prefer low-lying alluvial grasslands and their surroundings, with riparian forests and woodlands tied to the availability of water. Also, the species prefer the lowlands dominated by deciduous forests and with a marked dry season, where it apparently use small pools and marshes, in addition to permanently flowing rivers in Indochina (Hedges et al. 2008). They are probably grazers by preference, feeding mainly on grasses when available, but they also eat herbs, fruits and bark as well as browse trees and shrubs (Aryal et al. 2011). Saccharum spontaneum and Imperata cylindrica are the highly preferred grass species by wild water buffalo in KTWR with medium preference for Cynodon dactylon, Arundinella species, Dichanthium annulatum and Typha elephantine.

With the aim of establishing a second ecologically viable sub-population in its historic range, Government of Nepal $(\mathrm{GoN})$ has made decision (dated January $06,2015)$ to relocate 20 wild water buffalo ( 5 male and 15 female) to Chitwan National Park (CNP). Accordingly, 15 wild water buffalo (3 male and 12 female) of which three from the Central Zoo and 12 from KTWR have been successfully relocated to Old Padampur area of CNP in the year 2017 (DNPWC 2017). Moreover, the species is now soft released in a custom-built enclosure in the grassland of Old Padampur area of CNP. Re-introduction of the only viable population of a globally exterminating species into a potential habitat is a historic step towards conservation. This strategy, at its very best, can establish 
another viable sub-population and at its worst, can lead to ecological extinction if any of the catastrophic events occur. Thus, the detail study of habitat suitability analysis and other conservation issues are important for the conservation of reintroduced wild water buffalo. Habitat suitability assessment establishes relationships between occurrences of species and environmental conditions, which help to identify the areas for reserve and translocation of species including effective management of wildlife species (Osborne and Seddon 2009). For this endeavor, ground surveys along with Remote Sensing (RS) and Geographic Information System (GIS) technologies are the quickest and costeffective tools for the identification of suitable habitat and its mapping (Kushwaha, Roy 2002; Kafley 2008). However, in the context of insufficient study conducted on habitat suitability assessment of wild water buffalo in Nepal, this study could be an appropriate reference on population and habitat management of wild water buffalo for the wildlife managers, decision-makers and the government authorities. Therefore, the study aimed at mapping the habitat suitability of wild water buffalo in Chitwan National Park, analyzing habitat suitability based on the vegetation status, and assessing the conservation issues of re-introduced wild water buffalo in the release site.

\section{Materials and Methods}

\section{Study Area}

The study was conducted in February, 2018 in Old Padampur area of Chitwan National Park. CNP is situated in South-central Nepal in the subtropical lowlands of inner Tarai and covers an area of $952.63 \mathrm{~km}^{2}$. The national park is located between $27^{\circ} 20^{\prime} 19^{\prime \prime}$ to $27^{\circ} 43^{\prime} 16^{\prime \prime} \mathrm{N}$ and $83^{\circ} 44^{\prime} 50^{\prime \prime}$ to $84^{\circ} 45^{\prime} 03^{\prime \prime}$ E. Old Padampur area covers an area of approximately $21 \mathrm{~km}^{2}$ and lies in the northern part of CNP adjacent to Rapti river. Previously, there was human settlement in Old Padampur area. However, by realizing the importance of solving land use and wildlife conflicts issues, GoN had initiated human settlement relocation program in 1994, and was completedin 2002. After evacuation, Old Padampur area is converted into grassland. Few patches of riverine forests are emerging in recent years. The area has abundant water from the streams flowing from the Southern Churia hills. A few wetland sites like Patna lake and Marchauli ghol also provide crucial wallowing place for rhinos and drinking water for other wild animals (Kafley 2008). Recently, the GoN has declared this Old Padampur area as core of CNP (DNPWC 2017). After the extinction of wild water buffalo from CNP in the 1960s (Seidensticker 1975; IUCN 2019), the park has strived to revive wild water buffalo population by reintroducing 15 wild water buffaloes in the grassland of Old Padampur, which is the largest grassland in the park (DNPWC 2017). Location map of study area is presented in Figure 1. 


\section{Study Area Map}

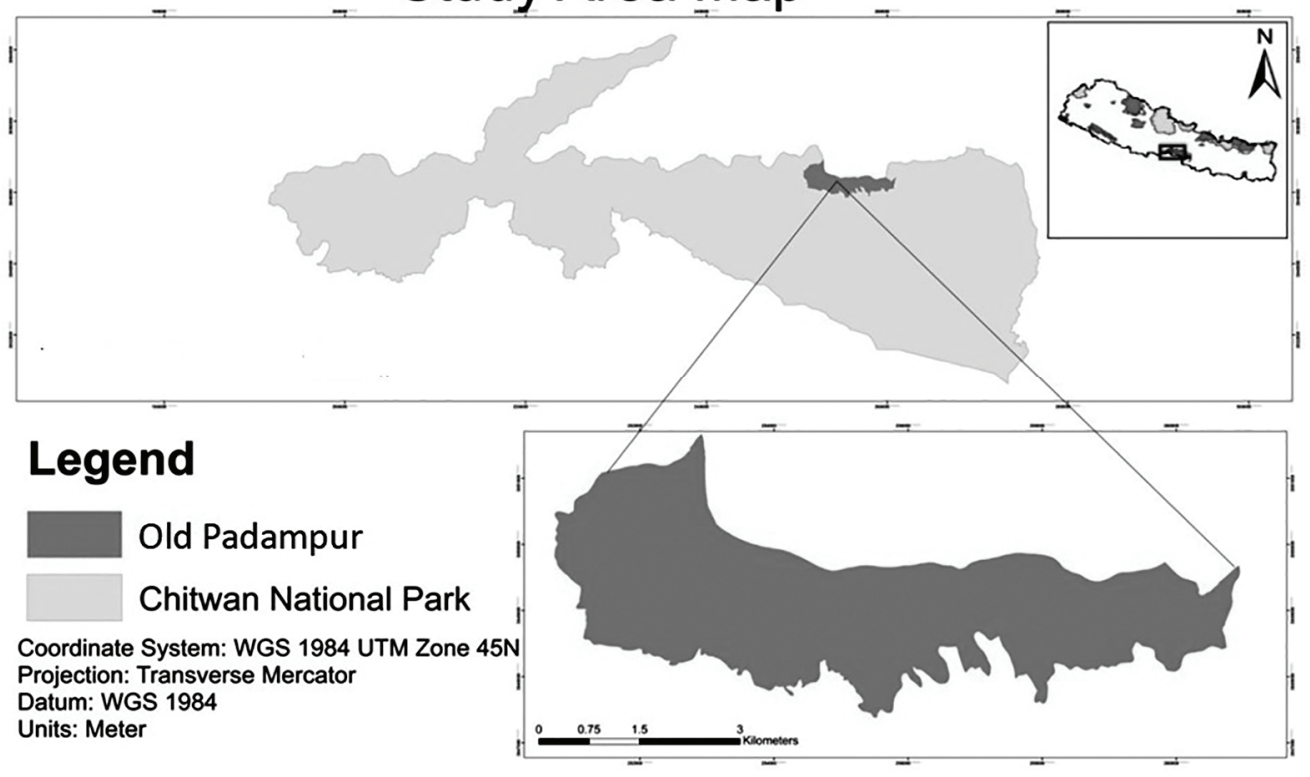

Figure 1 : Location Map of Study Area

\section{Methodology}

\section{Sample Design}

During the selection of sample plots, a minimum of $200 \mathrm{~m}$ distance between the center points of the sample plots were maintained in ArcGIS 10.2.2 "create random number" sampling tool. A total of 36 representative sample plots, each of size $1 \mathrm{~m} \times 1 \mathrm{~m}$ for grasses (Yan et al. 2005) and $10 \mathrm{~m} \times 10 \mathrm{~m}$ for trees species (Pokhrel et al. 2019) were laid down systematically in the Old Padampur area for vegetation analysis. The GPS receiver, Garmin Etrex 10 was used to locate the randomly designed sample plots.

\section{Habitat Analysis}

\section{Food (Grass species)}

Species composition, frequency and coverage of grasses and tree species along with their local and scientific names and GPS coordinates of each plot were recorded. Relative Density (RD), Relative Frequency (RF) and Relative Abundance (RA) were calculated to determine Importance Value Index (IVI).The concept of IVI has been developed for expressing the dominance and ecological success of any species, with a single value (Mishra 1968). 


\section{Water, Cover and Space}

Habitat components (water, cover and space) were obtained through LANDSAT-8 image analysis. For this, the cover and space were further divided into forest, grassland and river bank/barren land. The LANDSAT-8 image downloaded from USGS was classified by supervised classification using maximum likelihood algorithm to prepare land cover map, and the composition of the forest, grassland and river bank/barren land was determined. Systematic flow of habitat components is shown in Figure 2, and criteria adopted for preparing habitat suitability map are presented in Table 1.

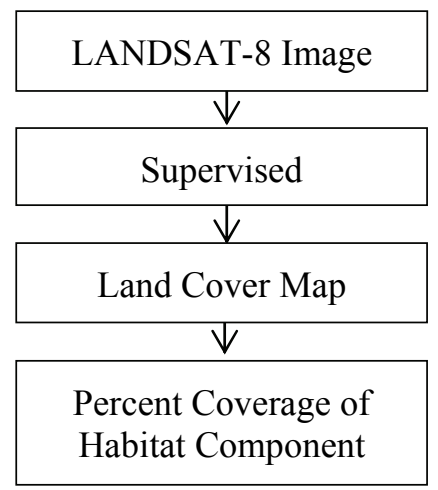

Figure 2 : Systematic Flow of Habitat Components Analysis

Table 1 : Criteria Adopted for Preparing Habitat Suitability Map

\begin{tabular}{|l|l|l|l|}
\hline S.N & Criteria & Measurement & References \\
\hline 1 & $\begin{array}{l}\text { Distance from water } \\
\text { source }\end{array}$ & Suitable: up to 3 km. & Parihar et al. (1986) \\
\hline 2 & Elevation & Up to 300m & Lamsal (2016) \\
\hline 3 & Slope & $\begin{array}{l}\text { Suitable: }<\text { 7 degree (Flat to } \\
\text { gently sloping) }\end{array}$ & $\begin{array}{l}\text { IUCN (2019), Pokhrel et } \\
\text { al.(2019) }\end{array}$ \\
\hline 4 & Land cover/use & $\begin{array}{l}\text { Suitable: grassland, water } \\
\text { bodies, riverbank, riverine } \\
\text { forest }\end{array}$ & Parihar et al. (1986) \\
\hline
\end{tabular}

\section{Habitat Suitability Analysis}

LANDSAT-8 image and ASTER DEM downloaded from USGS were used in suitability modeling and mapping. The downloaded LANDSAT-8 image was classified by supervised classification using maximum likelihood algorithm. Multi- criteria analysis was used to determine the suitable area. Land cover, slope, elevation and distance from water source were used to determine the suitable area. Each criterion was assigned the value of either 0 or 1 based on the above measurements where 0 means unsuitable and 1 means suitable. For the 
land cover, pure Sal forest was assigned 0 since this forest type is unsuitable for wild water buffalo (Parihar et al. 1986). In case of distance from water source up to $3 \mathrm{~km}$ distance was assigned 1. Slope less than 7 degree was assigned 1 and up to $300 \mathrm{~m}$ elevation was assigned 1 and else 0 . After reclassifying all of the criteria, they were multiplied in raster calculator to give the habitat suitability map of 0 and 1 where the former is unsuitable and later the suitable habitat. In this way, binary suitability modeling was used to determine the suitable habitat for wild water buffalo in CNP. The disturbance factors, i.e. roads and settlements were not used as suitability criteria. This is because all of the settlements lie outside the natural river boundary, which separates national park core zone from the buffer zone. Flow diagram of habitat suitability analysis is shown in Figure 3.

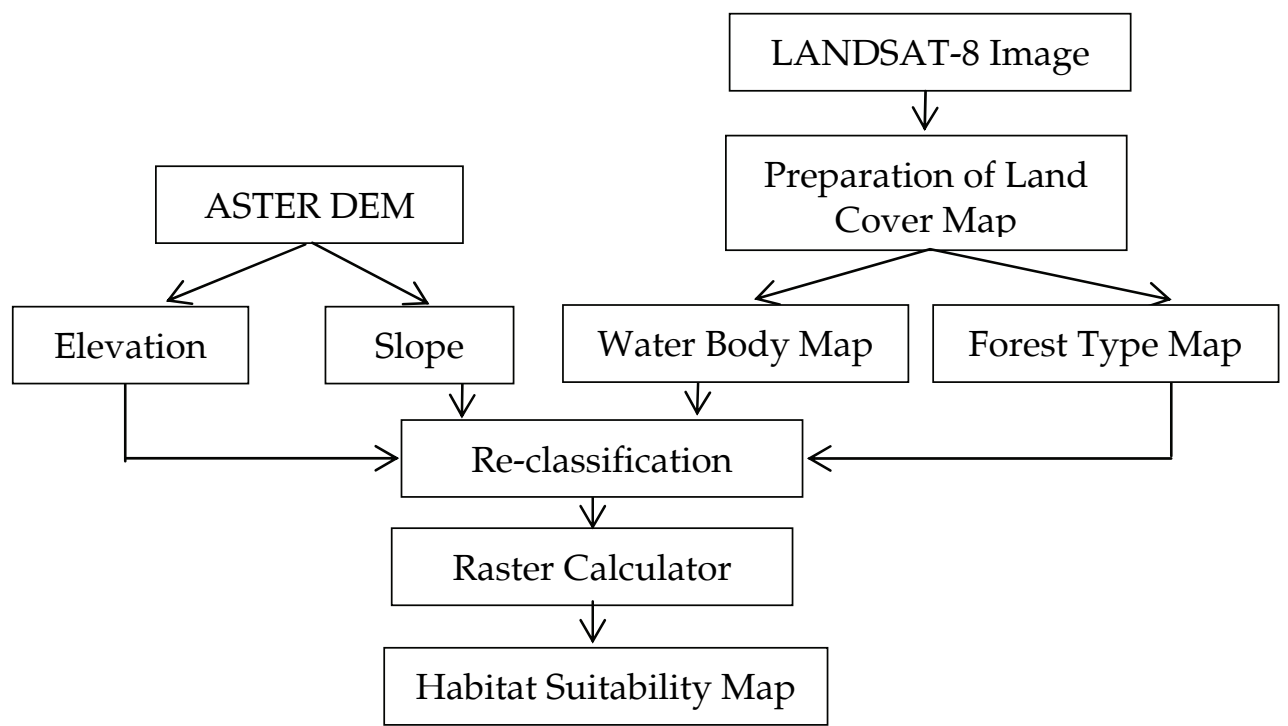

\section{Figure 3 : Methodological Flow Diagram of Habitat Suitability Analysis}

\section{Key Informant Interviews}

To ascertain the conservation issues of re-introduced wild water buffalo, interviews were held with the key officials at time and venue as per their convenience. The interviewees included Deputy Director General of DNPWC and former Chief Warden of CNP, incumbent Chief Warden and Assistant Wardens of CNP at Kasara and Sauraha sector, Officer of National Trust for Nature Conservation (NTNC), Wildlife Veterinary Doctor of CNP and Buffer Zone Management Committee - CNP representative. Altogether eight key informant interviews were conducted for this endeavor. 


\section{Results and Discussion}

A total of 20 species of grasses including scattered trees were recorded, out of which Saccharum spontaneum with IVI of 100.43 was the dominant grass species in Old Padampur area followed by Imperata cylindrica with IVI 56.70 (Figure 5). Saccharum spontaneum (IVI of 22.52) and Imperata cylindrica (IVI of 21.67) were almost equally abundant in the area followed by Saccharum arundinaceum (14.70) and Saccharum bengalense (10.26). But the relative density $(52.66 \%)$ and relative frequency $(25.24 \%)$ of Saccharum spontaneum was much higher than of other species making it the most dominant and most common frequently, thus, readily available species in the area. It is also interesting to note that tree species, although not dominant with almost no abundance, were frequent with Syzygium operculatum (IVI of 8.74) being the most frequent species closely followed by Bombax ceiba (IVI of 7.77) and Mangifera indica (IVI of 4.85). Thus, Old Padampur area is largely dominated by tall grasses. In comparison, over $80 \%$ of the area of KTWR was dominated by tall grasses (e.g. Saccharum, Phragmites, Imperata cylindrica) and beaches, with forests of Bombax ceiba, Dalbergia sissoo, Trewia nudiflora and Acacia catechu elsewhere. Previous studies showed that Saccharum spontaneum and Imperata cylindrica are the most preferred species of wild water buffalo. Similarly, Saccharum arundinaceum and S. spontaneum are the preferred foods of wild water buffalo in Thailand (Bolton 1975). The vegetation analysis, also, revealed that the most preferred habitat of wild water buffalo consists of Bombax ceiba, Dalbergia sissoo and Acacia catechu (Parihar et al. 1986). The IVI index of trees in the study area indicates the dominant species as Bombax ceiba followed by Syzygium operculatum, Dalbergia sissoo and Trewia nudiflora. Thus, the presence of such vegetation types preferred by wild water buffalo in CNP makes it more suitable for the translocation program. Importance Value Indices of different grass and tree species are presented in Figure 4. 


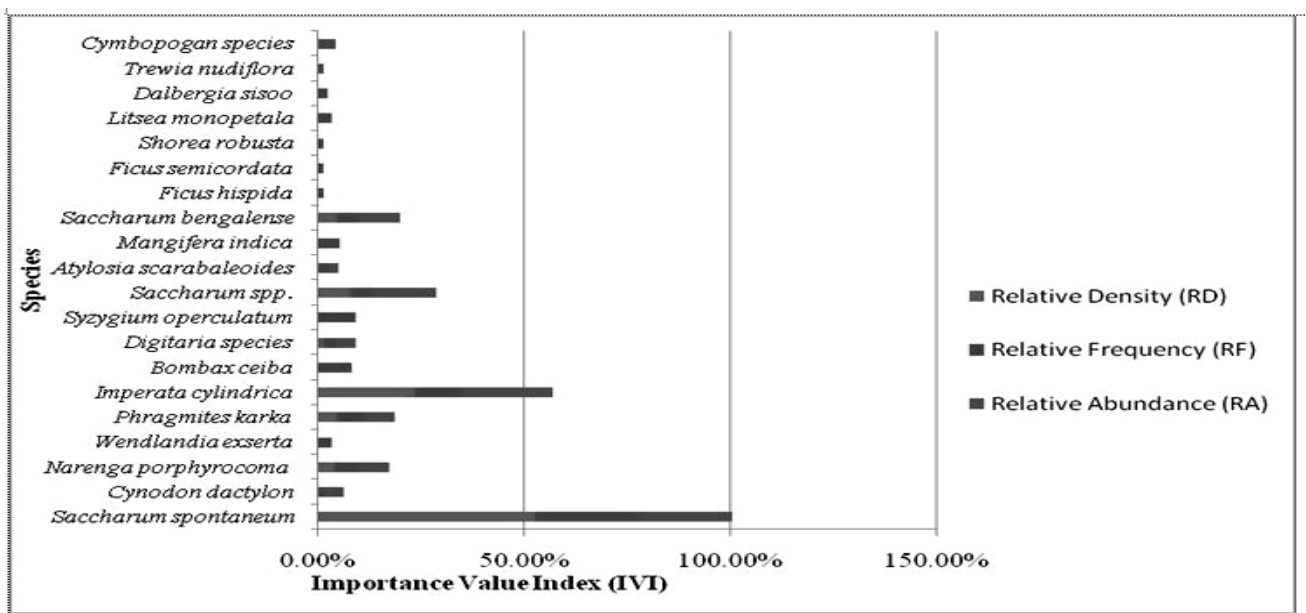

\section{Figure 4 : Importance Value Index of Grass and Tree Species in Old Padampur Area}

In order to determine the other habitat components (water, cover and space) composition in the Old Padampur area, the land cover map was prepared (Figure 5).

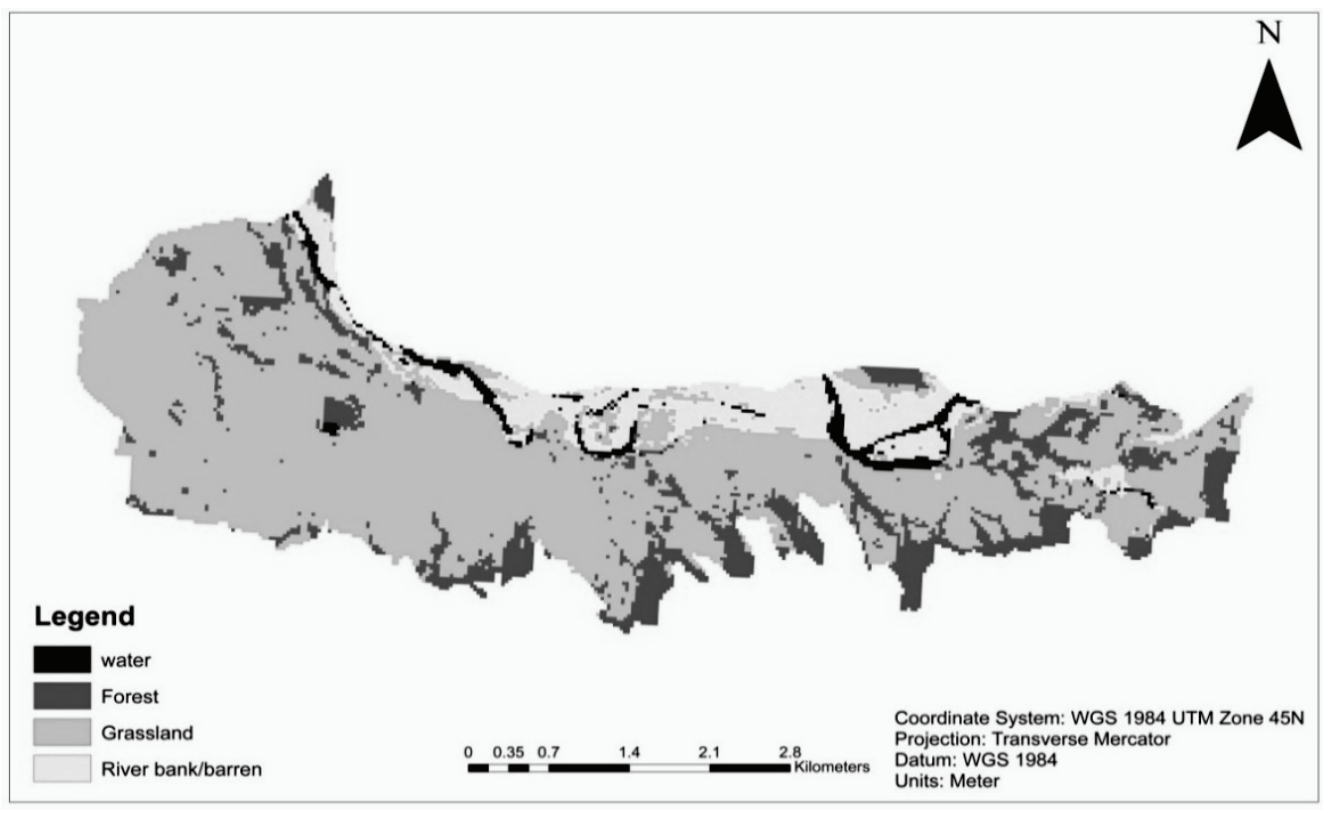

\section{Figure 5 : Land Cover Map of Old Padampur Area}

Based on the land cover map of Old Padampur area, the land cover comprises of $3 \%$ of water and water bodies, $11 \%$ river bank / barren land, $16 \%$ forest and $70 \%$ 
grassland (Figure 6). The result shows that Old Padampur area comprises more grassland areas supported by water bodies and open spaces i.e. river banks.

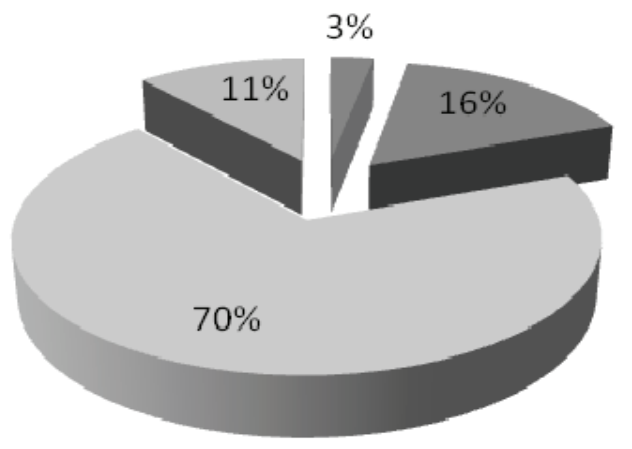

Water

Forest

Grassland

Riverbank/barren

\section{Figure 6 : Percentage of Land Cover in Old PadampurArea}

The wild population of wild water buffalo is confined to the swampy areas along the riverine areas and in the tropical and sub-tropical regions of Indian subcontinent and south-east Asia (Wharton 1957). Wild buffaloes are tied to the availability of water: historically their preferred habitats were low-lying alluvial grasslands and their surrounds, with riverine forests (Choudhury 1994). As Old Padampur area lies in the lap of Rapti river with the characteristics of floodplain riverine forest and grassland along with some water holes, its habitat and the habitat components are in good condition. But wild water buffaloes are confined in enclosure with an area of 22 ha with $643 \mathrm{~m}$ in length (East to West), 336m in the North and $300 \mathrm{~m}$ in the South with PCC foundation and mesh- wire supplemented with solar powered electric fencing around the enclosure for their adaptation to the new environment, and to prevent them from predators. The habitat suitability analysis showed that $27.13 \mathrm{~km}^{2}$, i.e. $13.35 \%$ of Chitwan National Park was found to be suitable habitat for wild water buffaloas shown in Figure 7. Most importantly, around 79\% of Old Padampur area, where the wild water buffaloes were released in an enclosure, was found to be suitable. It shows that the suitable areas are mostly distributed in the areas adjacent to the three river systems of CNP, i.e. Narayani, Rapti and Riu. 


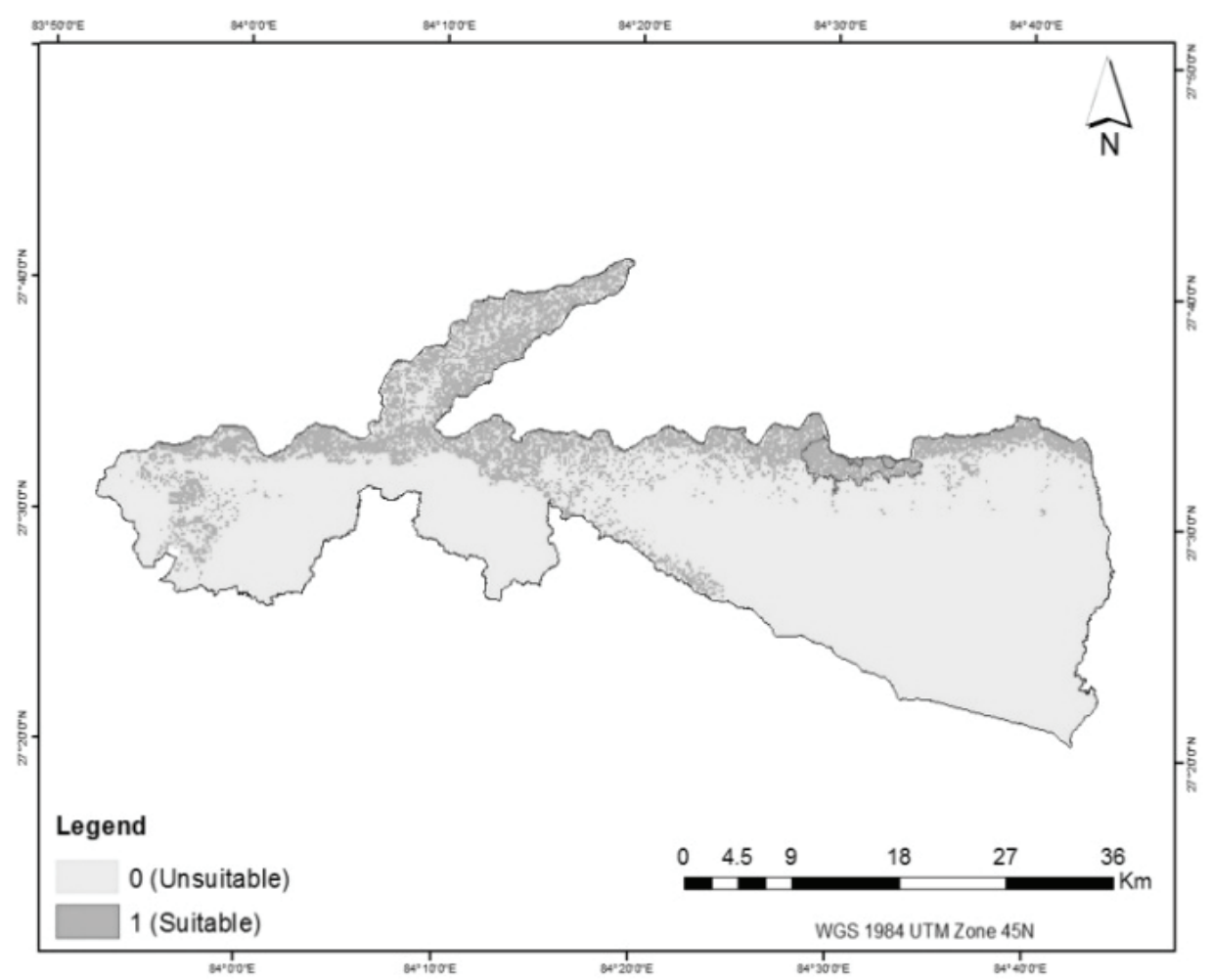

Figure 7 : Suitable Habitat for Wild Water Buffalo in CNP

Previous studies on habitat suitability modeling showed that $52.22 \mathrm{~km}^{2}$ of Babai flood plain of Bardia National Park was highly potential for wild buffalo (Lamsal 2016), and $403 \mathrm{~km}^{2}$ of the area of Chitwan National Park suitable for Rhino habitat (Kafley 2008). The probable reasons behind CNP being suitable for wild water buffalo are the presence of a mosaic of tall grasslands, short grasslands and riverine forests as well as plenty of wetlands and waterholes created by natural or artificial ox-bow lakes and water flowing from Churia (Khadka et al. 2016), which are quite similar to KTWR flood plain (Khatri et al. 2012).

Based on key-informant interviews and on-site observation of enclosure site of wild water buffalo, several issues were identified. For the stipulated number of translocation, the enclosure is not large enough to permit animals to engage socially with their own herd- mates. In addition, the havoc flood in Terai in 2017 (DNPWC 2017) has led to the shortage of palatable grass species inside the enclosure. Since then, food supplements are being given and crops are sown. But the question is for how long and what will be its implications. Since the enclosure is situated close to the Rapti flood plain, it seems to be an obstacle itself in seeking refuge in upland forest during flooding in the monsoon. Rigorous monitoring of translocated wild water buffalo and prompt damage 
assessment of enclosure are difficult because of inconvenient transport access. Moreover, the wild water buffaloes are expected to be in the enclosure for one more year with the expansion of enclosure but the translocation proposal (Heinen, Paudel 2015) recommends otherwise. Since translocation is a costly affair, and soft release is even more financially demanding, it could be accountable for the discrepancy in what should be and what has been.

\section{Conclusion}

Chitwan National Park is the historic habitat of wild water buffalo. This habitat suitability analysis of wild water buffalo in CNP under the environment of geospatial solutions concluded that around $13.35 \%$ of the park area was found to be suitable. Most importantly, around $79 \%$ of Old Padampur area, where the wild water buffaloes were released in an enclosure, was found to be suitable. Similarly, the vegetation analysis of Old Padampur area established that the area was suitable habitat for wild water buffalo. The frequent but less abundant trees provide perfect cover for this species and Old Padampur area lies within 500m distance from water source (Rapti river), which is the most suitable habitat for wallowing of this species. In terms of space, Old Padampur is the largest grassland of CNP. Thus, Old Padampur satisfies the four basic components of wildlife habitat, i.e. food, cover, water and space, and is a suitable habitat for wild water buffalo. After decades of recommendations made by many researchers and experts, the year 2017 was earmarked for re-introduction of wild water buffaloes, and 15 were translocated in the grassland of Old Padampur in an enclosure. Keeping them in an enclosure is vital for acclimatization, and more importantly, for maintaining herd size for anti-predator defense mechanism. But that can only be better achieved if number of other factors like enclosure size, population size and composition, herding behavior, stress factors and habitat component's intervention are taken into account. 


\section{Literature Cited}

Aryal, A., Shrestha, T.K., Ram, A., Frey, W., Groves, C., Hemmer, H., Dhakal, M., Koirala, R.K., Heinen, J.T., Raubenheimer, D. (2011): Call to conserve the wild water buffalo (Bubalus arnee) in Nepal. International Journal of Conservation Sciences, 2(4):161-168

Bolton, M. (1975): Royal Chitwan National Park Management Plan, 1975-1979. UNDP/FAO. http://www.iucn.org/dbtw-wpd/edocs/Bios-Cons-NatPro-541.35-008.pdf

Dahmer, T.D. (1978): Status and Ecology of the Wild Asian Buffalo in Nepal. Master thesis, University of Montana, Messenia, Montana.

DNPWC. (2017): Annual Report 2073-074. Department of National Parks and Wildlife Conservation, Kathmandu, Nepal.

DNPWC. (2018): Annual Report 2074-075. Department of National Parks and Wildlife Conservation, Kathmandu, Nepal.

Hedges, S., Baral, H.S., Timmins, R.J., Duckworth, J.W. (2008): Bubalus arnee. The IUCN Red List of Threatened Species 2008: e.T3129A9615891. http:/ /dx.doi.org/10.2305/IUCN.UK.2008.RLTS.T3129A9615891.en

Heinen, J.T., Paudel, P.K. (2015): On the translocation of wild Asian buffalo Bubalus arnee in Nepal: Are feral backcrosses worth conserving? Conservation Science, 3: 11-21.

IUCN. (2019): The IUCN Red List of Threatened Species, Version 2019-1. Gland, Switzerland.

Kafley, H. (2008): Habitat Evaluation and Suitability Modeling of Rhinoceros unicornis in Chitwan National Park: A Geospatial Approach. Project report submitted to Alcoa Foundation, Conservation and Sustainability Fellowship Program, Institute of International Education, USA.

Khadka, B.B., Lamichhane, B.R., Aryal, N. (2016): High prey density observed in village evacuated area: A case study from Padampur of Chitwan National Park.

http://www.chitwannationalpark.gov.np/index.php/news/doc_downloa d/41-prey-base-inpadampur

Khatri, T.B., Shah, D.N., Mishra, N. (2012): Wild water buffalo Bubalus arnee in Koshi Tappu Wildlife Reserve, Nepal: Status, population and conservation importance. Journal of Threatened Taxa, 4(14): 3294-3301. 
Kushwaha, S.P.S., Roy, P.S. (2002): Geospatial technology for wildlife habitat evaluation. Tropical Ecology, 43(1): 137-150.

Lamsal, B. (2016): Habitat Suitability Assessment of Wild Water Buffalo (Bubalus arnee) in the Babai Flood Plain of Bardia National Park. Bachelor's thesis submitted to Tribhuvan University.

Misra, R. (1968): Ecology Workbook. Oxford and IBH publishing Co., Calcutta.

Parihar, J.S., Kotwal, P.C., Panigrahi, S., Chaturvedi, N. (1986): Study of Wildlife Habitat Using High Resolution Space Photographs: A Case Study of Kanha National Park. ISRO-SP-17-86, Special Publication of Indian Space Research Organization, Space Applications Centre, Ahmedabad, 65-82 pp.

Pokhrel, K., Poudel, P., Neupane, B., Paudel, R. (2019): Comparative study in habitat suitability analysis of wild water buffalo (Bubalus arnee) in two flood plains of Chitwan National Park (CNP), Nepal. International Journal of Research Studies in Zoology, 5(3): 1-10.

Pradhan, N.M.B. (2007): A landscape approach in conserving large mammals: A case study from Western Terai, Nepal. The Initiation, 1: 44-55.

Seidensticker, L. (1975): Ungulate Population in Chitwan Valley, Nepal. Unpublished report, Office of Zoological Research, National Zoological Park, Smithsonian Institute, Washington, DC, USA.

Smith, J.L.D., Ahearn, S.C., Mc Dougal, C. (1998): Landscape analysis of tiger distribution and habitat quality in Nepal. Conservation Biology, 12 (6): 1338-1346.

Wharton, C.H. (1957): An Ecological Study of the Kouprey, Novibos sauveli (Urbain). Monograph no. 5, pp. 1-107. Monographs of the Institute of Science and Technology, Manila, The Philippines.

Yan, Y., Yun-ying, Z., Jian-hui, Z., Jian-guo, Z., Xiang-hao, Z. (2005): Diversity of plant species of alpine grassland in Nakchu of Tibet, China. Wuhan University Journal of Natural Sciences, 10(4): 659-664. 